\title{
Distribution of Pectobacterium Species Isolated in South Korea and Comparison of Temperature Effects on Pathogenicity
}

\author{
Samnyu Jee (iD) ${ }^{1 *}$, Jang-Gyu Choi ${ }^{1}$, Young-Gyu Lee ${ }^{1}$, Min Kwon ${ }^{1}$, Ingyu Hwang ${ }^{2}$, and Sunggi Heu ${ }^{3}$ \\ ${ }^{1}$ Highland Agriculture Research Institute, National Institute of Crop Science, Rural Development Administration, \\ Pyeongchang 25342, Korea \\ ${ }^{2}$ Department of Agricultural Biotechnology, Seoul National University, Seoul 08826, Korea \\ ${ }^{3}$ Crop Cultivation and Environment Research Division, National Institute of Crop Science, Rural Development Adminis- \\ tration, Suwon 16613, Korea
}

(Received on February 12, 2020; Revised on June 16, 2020; Accepted on June 23, 2020)

Pectobacterium, which causes soft rot disease, is divided into 18 species based on the current classification. A total of 225 Pectobacterium strains were isolated from 10 main cultivation regions of potato (Solanum tuberosum), napa cabbage (Brassica rapa subsp. pekinensis), and radish (Raphanus sativus) in South Korea; 202 isolates $(90 \%)$ were from potato, 18 from napa cabbage, and five from radish. Strains were identified using the Biolog test and phylogenetic analysis. The pathogenicity and swimming motility were tested at four different temperatures. Pectolytic activity and plant cell-wall degrading enzyme (PCWDE) activity were evaluated for six species (P. carotovorum subsp. carotovorum, Pcc; $P$. odoriferum, Pod; $P$. brasiliense, $\mathrm{Pbr}$; $P$. versatile, $\mathrm{Pve;}$ $P$. polaris, Ppo; P. parmentieri, Ppa). Pod, Pcc, Pbr, and Pve were the most prevalent species. Although $P$. atrosepticum is a widespread pathogen in other countries, it was not found here. This is the first report of Ppo, Ppa, and Pve in South Korea. Pectobacterium species showed stronger activity at $28^{\circ} \mathrm{C}$ and $32^{\circ} \mathrm{C}$ than at $24^{\circ} \mathrm{C}$, and showed weak activity at $37^{\circ} \mathrm{C}$. Pectolytic activity decreased with increasing temperature. Activity of pec-

*Corresponding author.

Phone) +82-33-330-1920, FAX) +82-33-330-1590

E-mail)jsnnimp@korea.kr

ORCID

Samnyu Jee

https://orcid.org/0000-0001-7834-4303

(c) This is an Open Access article distributed under the terms of the Creative Commons Attribution Non-Commercial License (http:// creativecommons.org/licenses/by-nc/4.0) which permits unrestricted noncommercial use, distribution, and reproduction in any medium, provided the original work is properly cited.

Articles can be freely viewed online at www.ppjonline.org. tate lyase was not significantly affected by temperature. Activity of protease, cellulase, and polygalacturonase decreased with increasing temperature. The inability of isolated Pectobacterium to soften host tissues at $37^{\circ} \mathrm{C}$ may be a consequence of decreased motility and PCWDE activity. These data suggest that future increases in temperature as a result of climate change may affect the population dynamics of Pectobacterium.

Keywords : pathogenicity, Pectobacterium, plant cell-wall degrading enzymes, soft rot, temperature

Handling Editor : Young-Su Seo

Pectobacterium species is one of the most important plant pathogenic bacteria and the causal agent of soft rot disease. Mansfield et al. (2012) placed $P$. carotovorum and $P$. atrosepticum $(\mathrm{Pa})$ at the tenth position in the top ten plant pathogenic bacteria based on economic loss. Four species of Erwinia, including E. chrysanthemi, and five subspecies of E. carotovorum were transferred to the Pectobacterium genus by Hauben et al. (1998). Pectobacterium carotovorum subsp. carotovorum (Pcc) is considered as a complex species because its strains show divergent characteristics ( $\mathrm{Li}$ et al., 2019). Additionally, Pectobacterium is a genus of the soft rot disease complex that also includes Dickeya (Charkowski, 2018). The taxonomic structure of Pectobacterium has been revised with several subspecies being elevated to the species level and new species derived from Pcc and P. wasabiae (Pw) (Gardan et al., 2003; Khayi et al., 2016; Oulghazi et al., 2019; Portier et al., 2019; Shirshikov et al., 2018; Waleron et al., 2018). According to the current classification, Pectobacterium is divided into 18 species: 
Pcc, Pa, P. aroidearum, P. aquaticum, P. betavasculorum, P. cacticidum, P. fontis, P. parmentieri (Ppa), P. polonicum, P. polaris (Ppo), P. peruviense, P. punjabense, $\mathrm{Pw}$, $P$. zantedeschiae, P. versatile (Pve), P. odoriferum (Pod), P. brasiliense ( $\mathrm{Pbr}$ ), and P. actinidiae (Brady et al., 2010; Dees et al., 2017; Duarte et al., 2004; Gardan et al., 2003; Khayi et al., 2016; Koh et al., 2012; Nabhan et al., 2012, 2013; Oulghazi et al., 2019; Pédron et al., 2019; Portier et al., 2019; Sarfraz et al., 2018; Waleron et al., 2018, 2019b, 2019c). Of the 18 species, P. fontis, P. aquaticum, $P$. polonicum, and Pve were isolated from aquatic ecosystems including, groundwater, waterways, waterfalls, and streams.

In South Korea, napa cabbage (Brassica rapa subsp. pekinensis) and potato (Solanum tuberosum) are cultivated in highlands during summer and in lowlands during fall to avoid high temperatures and outbreak of disease. In addition, there is an annual rotation of potato cultivation with napa cabbage cultivation to avoid replant failure as a result of continuous cropping in highland. Recently, the temperature of highlands has been slowly increasing, and soft rot disease incidence is an emerging problem in highland potato cultivation. No et al. (2009) reported a 130 ha field loss of napa cabbage cultivation as a result of Pectobacterium infection. In South Korea, Pcc, Pbr, Pod, and Pa have been reported to cause soft rot disease in various crops including potato and napa cabbage (Lee et al., 2014; Park et al., 1999; Roh et al., 2009; Seo et al., 2004). P. actinidiae was confirmed as a pathogen of canker in kiwifruit (Koh et al., 2012). Of the Pectobacterium species, Pcc is known to be the predominant cause of soft rot disease in South Korea (Kang et al., 2003). However, the taxonomy of Pectobacterium has changed dramatically in recent studies, and the species formerly identified as Pcc and Pw have been reclassified as new species (Khayi et al., 2016; Oulghazi et al., 2019; Waleron et al., 2018). The objective of this study was to identify the Pectobacterium species collected from South Korea based on the current taxonomy.

\section{Materials and Methods}

Sample collection. During 2016-2017, disease surveys were conducted to estimate the incidence of soft rot disease in potato, napa cabbage, and radish (Raphanus sativus). Field selection was based on the major area of cultivation for the three crops. For sample collection, infected plant tissues were randomly collected during the growing season from ten growing areas in South Korea: Hongcheon, Gangneung, Pyeongchang, Jeongseon, Yeongwol, Muju, Geochang, Miryang, Boseong, and Jeju. The infected plant tissues were first sterilized with $1 \%$ hypochlorite solution for $90 \mathrm{~s}$, then rinsed in distilled water, and then macerated with $1 \mathrm{ml}$ of distilled water. The suspension was streaked on Luria-Bertani (LB; BD, Franklin Lakes, NJ, USA) agar medium to isolate soft rot pathogens. The isolated strains were further cultured in LB broth with shaking at $28^{\circ} \mathrm{C}$ overnight $(16 \mathrm{~h})$. Strains were preserved in $20 \%$ glycerol $(\mathrm{v} / \mathrm{v})$ at $-72^{\circ} \mathrm{C}$. For comparison and identification of these isolated strains, we obtained 35 strains from the Microbial Safety Team (MST) and two strains from the National Agrobiodiversity Center (NAC), National Institute of Agricultural Sciences (NAS), Rural Development Administration (RDA).

Isolation of genomic DNA and phylogenetic analysis. Genomic DNA of all strains was extracted using the Gspin Genomic DNA Extraction Kit (Intron Biotechnology, Seongnam, Korea) according to the manufacturer's instructions. To identify the strains, the 16S rRNA and recombinase A ( $\operatorname{rec} A)$ gene were sequenced using Macrogen (Seongnam, Korea) with the following primers: 27F, 5'-AGAGTTTGATCMTGGCTCAG-3'; 1492R, 5'-TACGGYTACCTTGTTACGACTT-3'; Ec_recA_F, 5'-GGTAAAGGGTCTATCATGCG-3'; and Ec_recA_ R, 5'-CCTTCACCATACATAATTTGGA-3' (Lee et al., 2014; Waleron et al., 2002). A multilocus sequence analysis was performed on concatenated sequences of two genes with alignment by ClustalW and 1,000 bootstraps in the MEGA7 program (Kumar et al., 2016; Larkin et al., 2007). Phylogenetic analysis was performed by the neighbor-joining method (Saitou and Nei, 1987). Twenty-four sequences of 13 reference strains were retrieved from NCBI (Table 1).

Biolog and pathogenicity tests. Carbon source usage of the isolated strains was evaluated using Biolog GENIII MicroPlate (Biolog, Hayward, CA, USA), according to the manufacturer's instructions. To compare changes in pathogenicity by temperature, $40 \mu 1$ of bacterial suspension was inoculated into holes made using a cork-borer on potato tuber slices and napa cabbage stems. Each plant tissue was incubated for $16 \mathrm{~h}$ at four different temperatures $-20^{\circ} \mathrm{C}$, $28^{\circ} \mathrm{C}, 32^{\circ} \mathrm{C}$, and $37^{\circ} \mathrm{C}$. The diameter of the macerated tissue was measured.

Determination of cardinal temperatures and motility tests. To confirm cardinal temperatures of Pectobacterium species, the growth of the isolated strains and reference strains were tested over a range of eight temperatures from $10^{\circ} \mathrm{C}$ to $45^{\circ} \mathrm{C}$ on tryptic soy agar (BD) media. Bacterial growth was evaluated at $24 \mathrm{~h}$ after inoculation, and for two 
Table 1. List of reference species and their GenBank accession numbers

\begin{tabular}{|c|c|c|c|}
\hline \multirow{2}{*}{ Species } & \multirow{2}{*}{ Strains $^{\mathrm{a}}$} & \multicolumn{2}{|c|}{ GenBank accession nos. } \\
\hline & & 16S rRNA & $\operatorname{rec} A$ \\
\hline Pectobacterium atrosepticum & SCRI1043 & NC_004547.1 & BX950851.1 \\
\hline P. betavasculorum & IFB5268 & KF704795.1 & KF704801.1 \\
\hline P. brasiliense & SX309 & NZ_CP020350.1 & NZ_CP020350.1 \\
\hline P. carotovorum subsp. carotovorum & NCPPB $312^{\mathrm{T}}$ & NZ_JQHJ01000004.1 & NZ_JQHJ01000014.1 \\
\hline P. odoriferum & BC S7 & СР009678.1 & СР009678.1 \\
\hline P. parmentieri & RNS08-42-1 $\mathrm{A}^{\mathrm{T}}$ & NR_153752.1 & СР015749.1 \\
\hline P. peruviense & $\mathrm{UGC} 32^{\mathrm{T}}$ & NZ_AODU01000014.1 & NZ_AODU01000002.1 \\
\hline P. polaris & NIBIO1006 ${ }^{\mathrm{T}}$ & NR_159085.1 & СР0- 17481.1 \\
\hline P. polonicum & DPMP315 & MK240326.1 & RJTN01000017.1 \\
\hline P. punjabense & $\mathrm{SS} 5^{\mathrm{T}}$ & MH249622.1 & MK517165.1 \\
\hline P. versatile & IFB5214 & MK024784.1 & MK024772.1 \\
\hline P. wasabiae & CFBP $3304^{\mathrm{T}}$ & NR_118294.1 & СР015750.1 \\
\hline P. zantedeschiae & $9 \mathrm{M}^{\mathrm{T}}$ & RYC46223.1 & MG761828.1 \\
\hline
\end{tabular}

${ }^{\mathrm{a}} \mathrm{T}$, type strain.

temperatures $\left(10^{\circ} \mathrm{C}\right.$ and $\left.15^{\circ} \mathrm{C}\right)$, growth was evaluated at 48 h. Motility was measured on LB medium with $0.3 \%$ agar according to Lee et al. (2013). To test the effect of temperature on motility, each strain was incubated at $24^{\circ} \mathrm{C}, 28^{\circ} \mathrm{C}$, $32^{\circ} \mathrm{C}$, and $37^{\circ} \mathrm{C}$ for $24 \mathrm{~h}$.

Pectolytic activity on semi-selective media. To test pectolytic activity at different temperatures, isolated bacteria were cultured in $\mathrm{LB}$ media for $16 \mathrm{~h}$ at $28^{\circ} \mathrm{C}$, and bacterial suspension was obtained by diluting with LB to an optical density of 0.5 at $600 \mathrm{~nm}$, measured using a spectrophotometer (DS-11, DeNovix, Wilmington, DE, USA). As the semi-selective medium, we used a single layer-crystal violet pectate (SL-CVP) medium made using pectin from citrus peel (P9135, Sigma-Aldrich, St. Louis, MO, USA) according to Hélias et al. (2012). Five microliters of each bacterial suspension were inoculated on potato tuber slices and SL-CVP media. The inoculated SL-CVP media were incubated at $28^{\circ} \mathrm{C}$ for $16 \mathrm{~h}$. The dilution solution was used as the negative control.

Plant cell-wall degrading enzyme (PCWDE) assay. Extracellular enzyme assays including cellulase $(\mathrm{Cel})$, polygalacturonase (Peh), pectate lyase (Pel), and protease (Prt) were performed according to Lee et al. (2013). To compare the effect of temperature on the enzymes, bacterial cells were grown in $\mathrm{LB}$ broth at $24^{\circ} \mathrm{C}, 28^{\circ} \mathrm{C}$, and $37^{\circ} \mathrm{C}$. Supernatants were collected by centrifuging the bacterial cells at 5,800 $\times \mathrm{g}$ for $5 \mathrm{~min}$ and were used for enzyme assays. Peh, Pel, and Cel activities were measured after 16-18 h of inoculation, and Prt activity was measured after $36 \mathrm{~h}$ of inoculation.

\section{Results and Discussion}

Disease incidence and isolation of Pectobacterium species. Our nationwide survey of soft rot disease incidence showed higher disease incidence in the highland cultivation during summer than in the lowland cultivation during fall (Fig. 1). Since potato and napa cabbage are cultivated by rotation, leaf and stem samples were collected from both crops to isolate Pectobacterium spp. A total of 225 strains were isolated and analyzed. Based on the 16S rRNA and rec $A$ gene analyses, 73 isolates $(32.4 \%)$ were Pod, 62

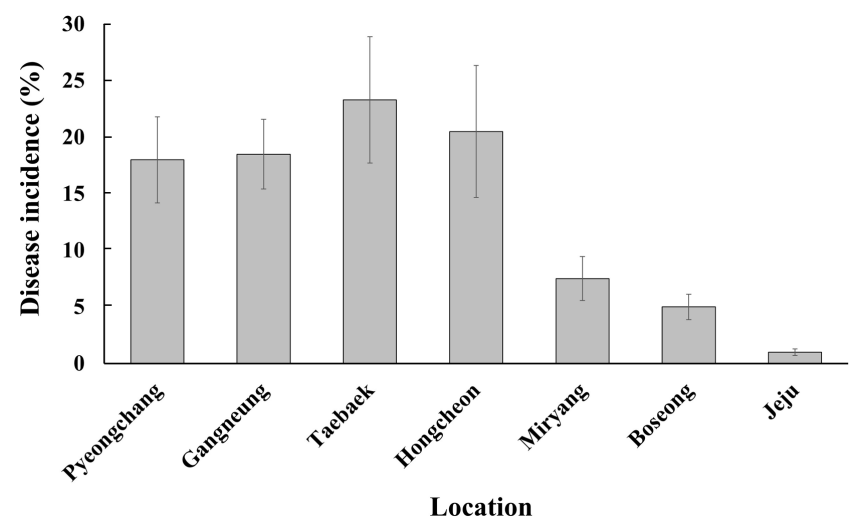

Fig. 1. Incidence of soft rot on potato and napa cabbage in seven areas of Korea during 2016-2017. Incidence of soft rot on potato and napa cabbage in Pyeongchang, Gangneung, Taebaek and Hongcheon was evaluated in the summer; in Miryang, Boseong, and Jeju, evaluation was done in the fall. 


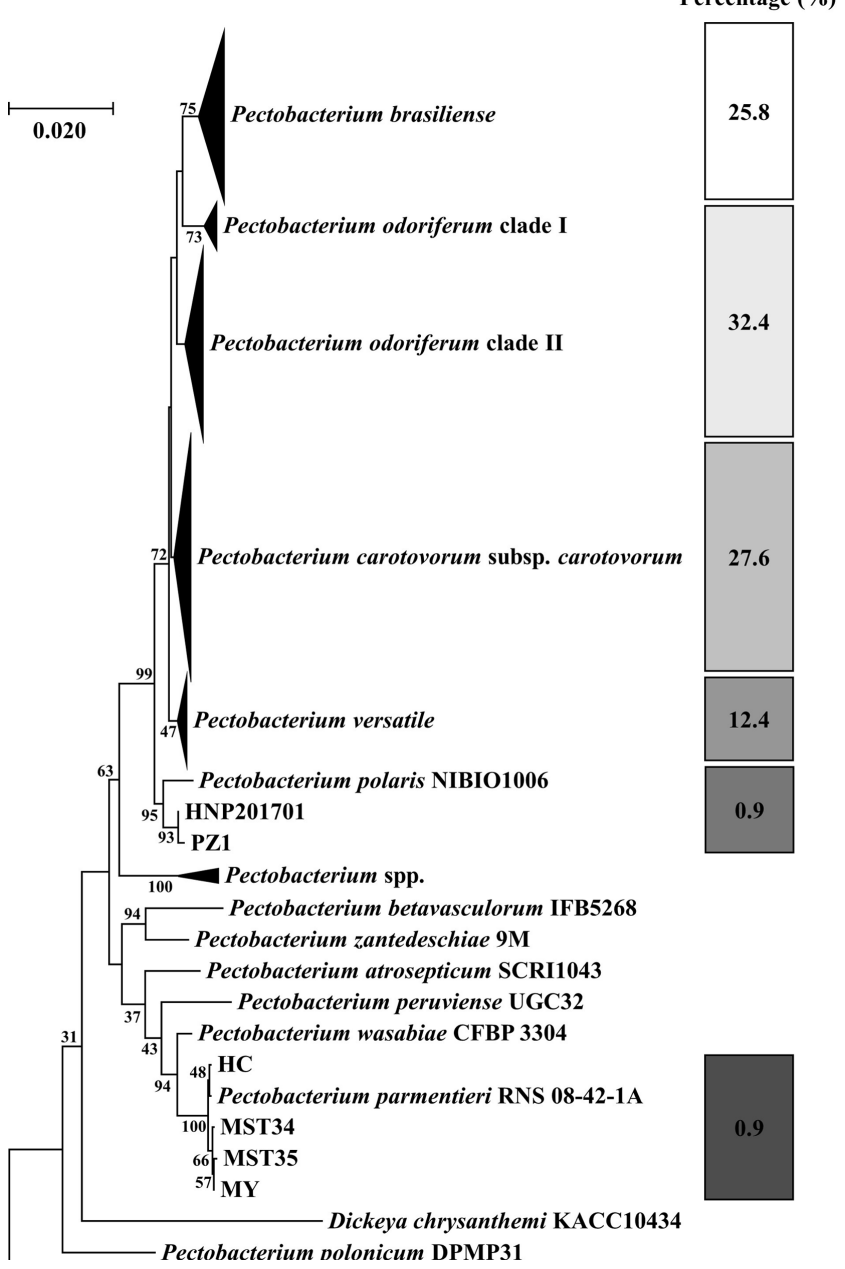

Fig. 2. A concatenated neighbor-joining phylogenetic analysis of 225 Pectobacterium strains based on 16S rRNA and recA gene sequences. This analysis was performed with 225 isolated strains and 48 reference strains. This collection was divided into 6 clades including $P$. odoriferum, $P$. carotovorum subsp. carotovorum, $P$. brasiliense, $P$. versatile, $P$. parmentieri, and $P$. polaris.

(27.6\%) were Pcc, 58 (25.8\%) were Pbr, and 28 (12.4\%) were Pve (Fig. 2). Additionally, two isolates each of Ppo and Ppa were obtained. This is the first report of Ppo in South Korea. In total, four Ppa isolates were identifiedone each from the samples collected in Hongcheon and Miryang, respectively, and two from the strains obtained from the MST. Given that the MST samples were collected during 1997-2000 and Ppa strains were identified in this collection, it can be assumed that Ppa isolates have existed in South Korea for at least 20 years. Eight known species of the soft rot disease complex were not present among the 225 isolated strains: $\mathrm{Pa}, P$. betavasculorum, $P$. peruviense, $P$. polonicum, $P$. punjabense, $\mathrm{Pw}, P$. zantedeschiae, and Dickeya sp. All 225 isolates grew well at $37^{\circ} \mathrm{C}$ in LB me- dium.

It is interesting to note that $\mathrm{Pa}$ was not isolated from any sample obtained from potato fields in South Korea in this study. Park et al. (1999) reported isolating Pa in South Korea, but we were unable to identify this species in this study. Pa had been considered as a major agent of potato blackleg and soft rot in Europe including Great Britain (Skelsey et al., 2018). However, the prevalence of Pa had decreased by the climate change during two decades except Scotland (van der Wolf et al., 2017). Skelsey et al. (2018) reported that three species including Ppa, Pbr, and Dickeya solani were predominant in Great Britain. The climate of South Korea is known to be a mixed region with temperate regions and subtropical regions (Kwon et al., 2007). Even in temperate climates, it is difficult to isolate $\mathrm{Pa}$ (Toth et al., 2003).

Distribution of Pectobacterium species. Pectobacterium spp. were collected from 10 of the main potato, napa cabbage, and radish cultivation areas in South Korea (Table 2, Fig. 1). Of the 225 identified strains, 174 isolates (77.3\%) were from summer cultivation and only $48(21.3 \%)$ isolates were from fall cultivation areas. Further, 202 isolates (89.8\%) of the 225 strains were from potato plants, and only 18 isolates were from napa cabbage, and 5 were from the radish. However, the potato was the only host from which Pectobacterium was isolated during fall. Temperature may be crucial to the success of Pectobacterium infection. In South Korea, summer cultivation starts from May and ends around August. From the end of June, when the potato plants start vegetative growth, temperature increases to above $25^{\circ} \mathrm{C}$ and reaches more than $30^{\circ} \mathrm{C}$ (Supplementary Fig. 1). However, during the fall cultivation of potato plants, the temperature at the start of the cultivation period is above $30^{\circ} \mathrm{C}$ but decreases to $10^{\circ} \mathrm{C}$ (Supplementary Fig. 2). Therefore, the temperature during the three months of summer cultivation is good for Pectobacterium activity. However, the decreasing temperature during fall cultivation may be too low for Pectobacterium activity.

Pod, Pcc, Pbr, and Pve were the most commonly found Pectobacterium spp. in samples from potato fields in South Korea. It is interesting to note that although Pod has mostly been considered to be primarily isolated from vegetables including napa cabbage in other countries (Charkowski, 2018), it has been isolated from potatoes in South Korea (Thapa et al., 2011), Algeria (Yahiaoui-Zaidi et al., 2010), and the United States (Ahmed et al., 2018). Also, Waleron et al. (2014) showed that Pod could induce soft rot symptoms on potato in laboratory conditions. In our study, 73 of the 225 isolates were identified as Pod, of which 56 of the 


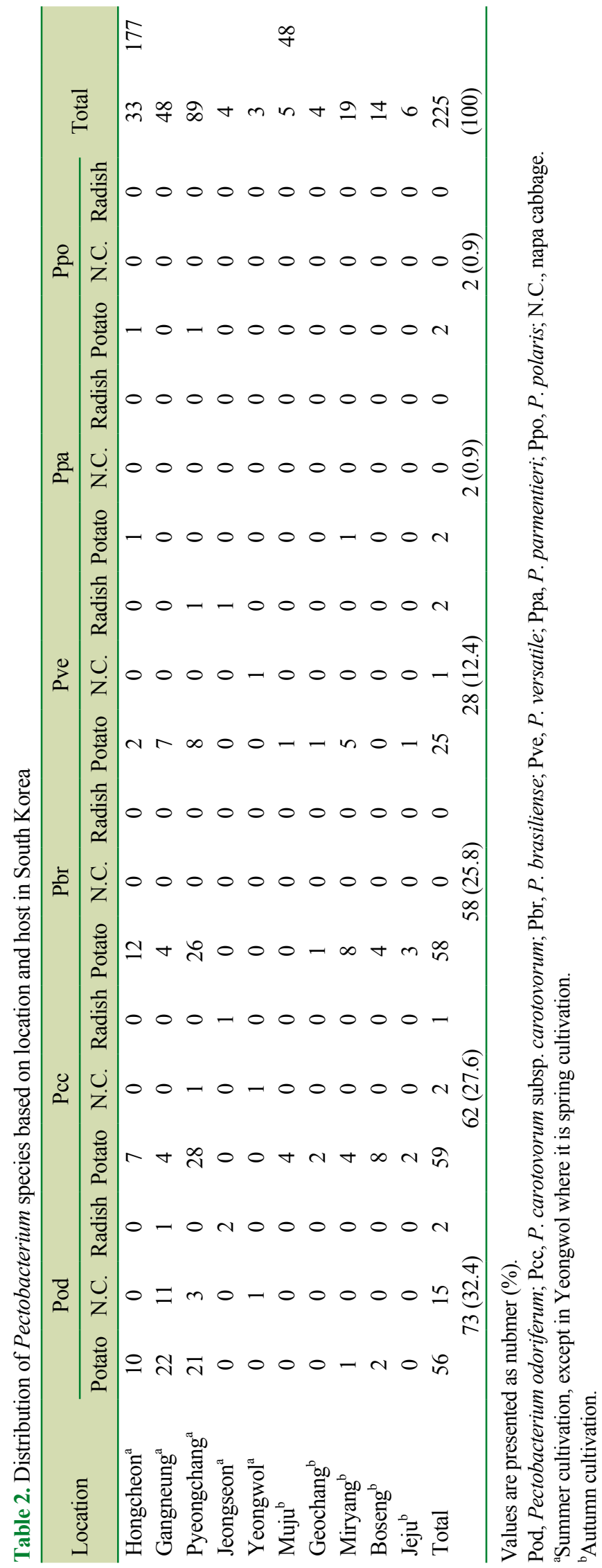

73 isolates were isolated from potato. A biochemical test was performed to verify this, as Pod can ferment sorbitol (Supplementary Table 1). The high population of Pod in potato fields in South Korea may be because of the crop rotation with napa cabbage. Many farmers rotate potato and napa cabbage cultivation to avoid gradual yield decline by continuous cultivation. Residues in the soil from the previous napa cabbage cultivation after tillage could be the inoculum source for the next potato crop. Pve has been reclassified in recent studies, and it has been reported in Europe, North America, North Africa, and Syria (Portier et al., 2019; Shirshikov et al., 2018; Waleron et al., 2019a). This is the first report of Pve in South Korea.

Effects of temperature on pathogenicity of Pectobacterium. At $20^{\circ} \mathrm{C}$, very little maceration of potato was observed, whereas no maceration was observed in napa cabbage (Fig. 3). The maceration of potato and napa cabbage varied slightly but was not significantly different between $28^{\circ} \mathrm{C}$ and $32^{\circ} \mathrm{C}$. Interestingly, no maceration was observed on either potato tuber slices or napa cabbage stems at $37^{\circ} \mathrm{C}$. No difference in maceration was noted with respect to the host plant of the isolates. The strains isolated from potato or napa cabbage showed the same maceration ability on potato and napa cabbage at $28^{\circ} \mathrm{C}$. In addition, pathogenicity was found to differ significantly: Pod showed the strongest activity in the maceration of potato and napa cabbage, and Ppa showed the weakest activity. Little is known about Pectobacterium response to environmental factors such as temperature. $\mathrm{Pa}, \mathrm{Ppa}$, and $\mathrm{Pw}$ mainly cause disease at $18-22^{\circ} \mathrm{C}$ and cannot grow at $37^{\circ} \mathrm{C}$ (Charkowski, 2018). In this study, Ppa showed a similar response at $37^{\circ} \mathrm{C}$ (Fig. 3, Supplementary Fig. 3). In a growth test on media, multiple comparisons between $\mathrm{Pcc}, \mathrm{Pa}$, and D. solani at four different temperatures $\left(18^{\circ} \mathrm{C}, 22^{\circ} \mathrm{C}\right.$, $26^{\circ} \mathrm{C}$, and $30^{\circ} \mathrm{C}$ ) revealed a slower Pa growth in $26^{\circ} \mathrm{C}$ and $30^{\circ} \mathrm{C}$ treatment conditions; in contrast, the growth of Pcc and D. solani increased as the temperature increased (Lebecka et al., 2018). Czajkowski et al. (2017) suggested that several genes in D. solani are temperature-regulated, perhaps more are upregulated at higher temperatures than at lower temperatures, and affect the expression of the virulence factors, which differs from previous results. This is thought to be a result of adaptation of $D$. solani to higher temperatures in Europe (Czajkowski et al., 2017). This study suggests that Pectobacterium species could also have such temperature-regulated genes that affect multiplication; 


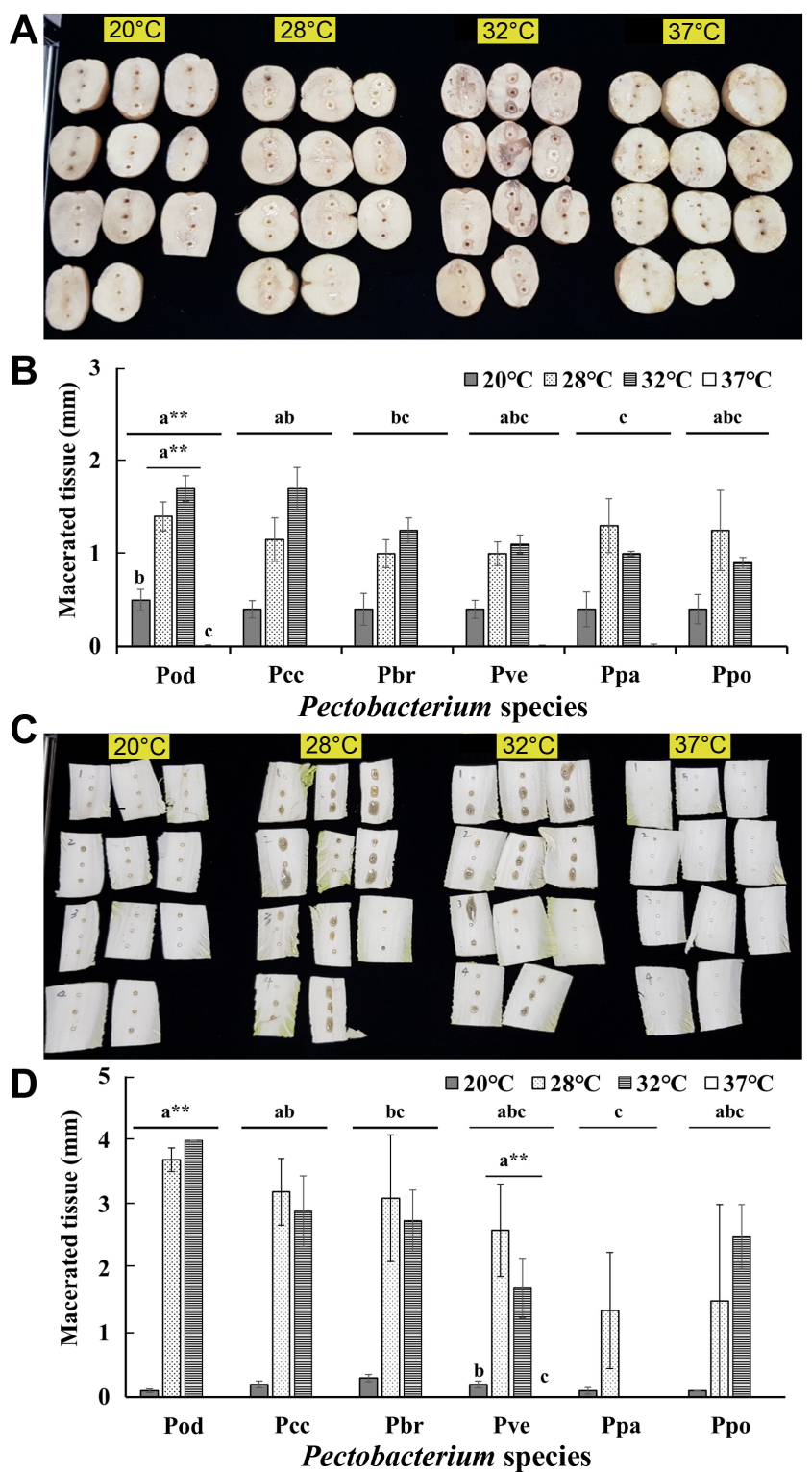

Fig. 3. The diameter of macerated tissue in potato and napa cabbage inoculated with Pectobacterium species. The inoculated tissues of potato $(\mathrm{A}, \mathrm{B})$ and napa cabbage $(\mathrm{C}, \mathrm{D})$ were incubated at four different temperatures: $20^{\circ} \mathrm{C}, 28^{\circ} \mathrm{C}, 32^{\circ} \mathrm{C}$, and $37^{\circ} \mathrm{C}$. Pod, Pectobacterium odoriferum; Pcc, $P$. carotovorum subsp. carotovorum; Pbr, P. brasiliense; Pve, P. versatile; Ppa, P. parmentieri; Ppo, P. polaris; $\mathrm{Pa}, P$. atrosepticum. Different letters indicate significant difference according to ANOVA with Duncan test at $* * P$ $<0.01$

the thermal response could, hence, be different among different species.

Effects of temperature on motility and pectolytic activity of Pectobacterium. The pathogenicity was highest at $28^{\circ} \mathrm{C}$ and $32^{\circ} \mathrm{C}$, and no pathogenicity was observed at

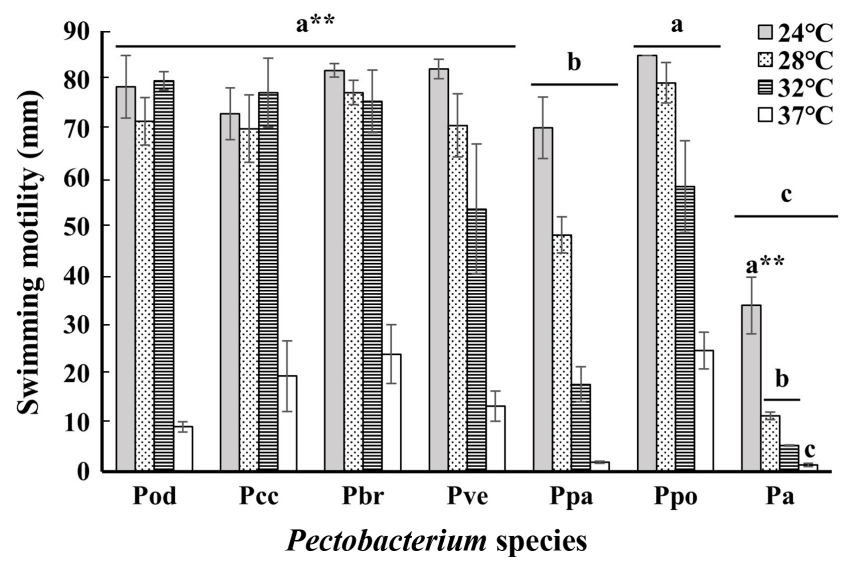

Fig. 4. Comparison of swimming motility of Pectobacterium species at four different temperatures. Pod, Pectobacterium odoriferum; Pcc, P. carotovorum subsp. carotovorum; Pbr, P. brasiliense; Pve, P. versatile; Ppa, P. parmentieri; Ppo, P . polaris; $\mathrm{Pa}$, $P$. atrosepticum. Different letters indicate significant difference according to ANOVA with Duncan test at $* * P<0.01$. This test was performed with 7 Pectobacterium species including a reference strain of $P$. atrosepticum.

$37^{\circ} \mathrm{C}$. In order to investigate whether temperature affected the viability of the bacterium or its pectolytic activity as the key factor for soft rot pathogenicity, we assessed the swimming motility and pectolytic activity of the isolated bacteria. The swimming motility of Pod, Pcc, and Pbr was stable up to $32^{\circ} \mathrm{C}$ but markedly reduced at $37^{\circ} \mathrm{C}$; however, the motility of Pve, Ppa, and Ppo reduced gradually with increasing temperature (Fig. 4). Therefore, the reduced swimming motility of Pectobacterium at $37^{\circ} \mathrm{C}$ may be why

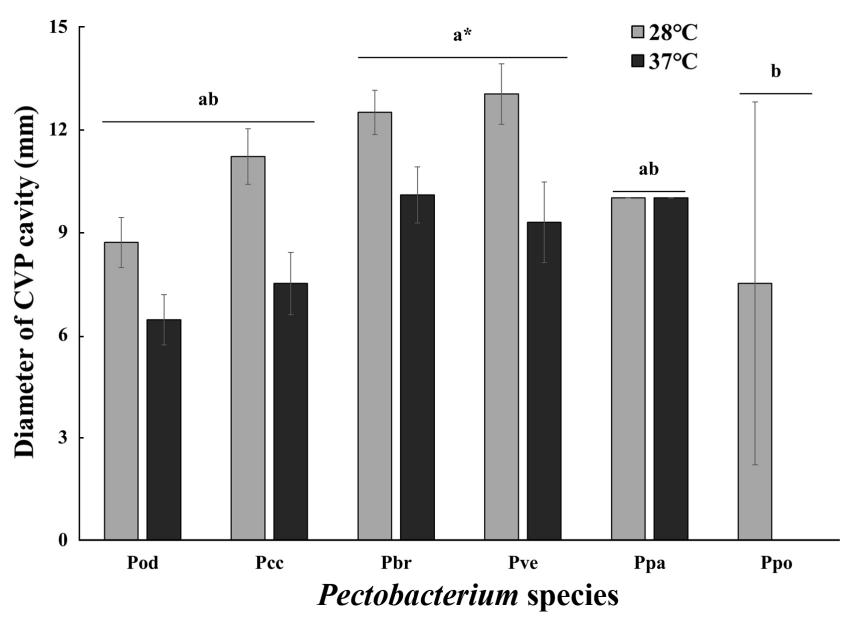

Fig. 5. Comparison of pectolytic activity with Pectobacterium species at $28^{\circ} \mathrm{C}$ and $37^{\circ} \mathrm{C}$. The assessment of pectolytic activity was performed with diameter of a cavity on crystal violet pectate (CVP) medium. Different letters indicate significant difference according to ANOVA with Duncan test at $* P<0.05$. 

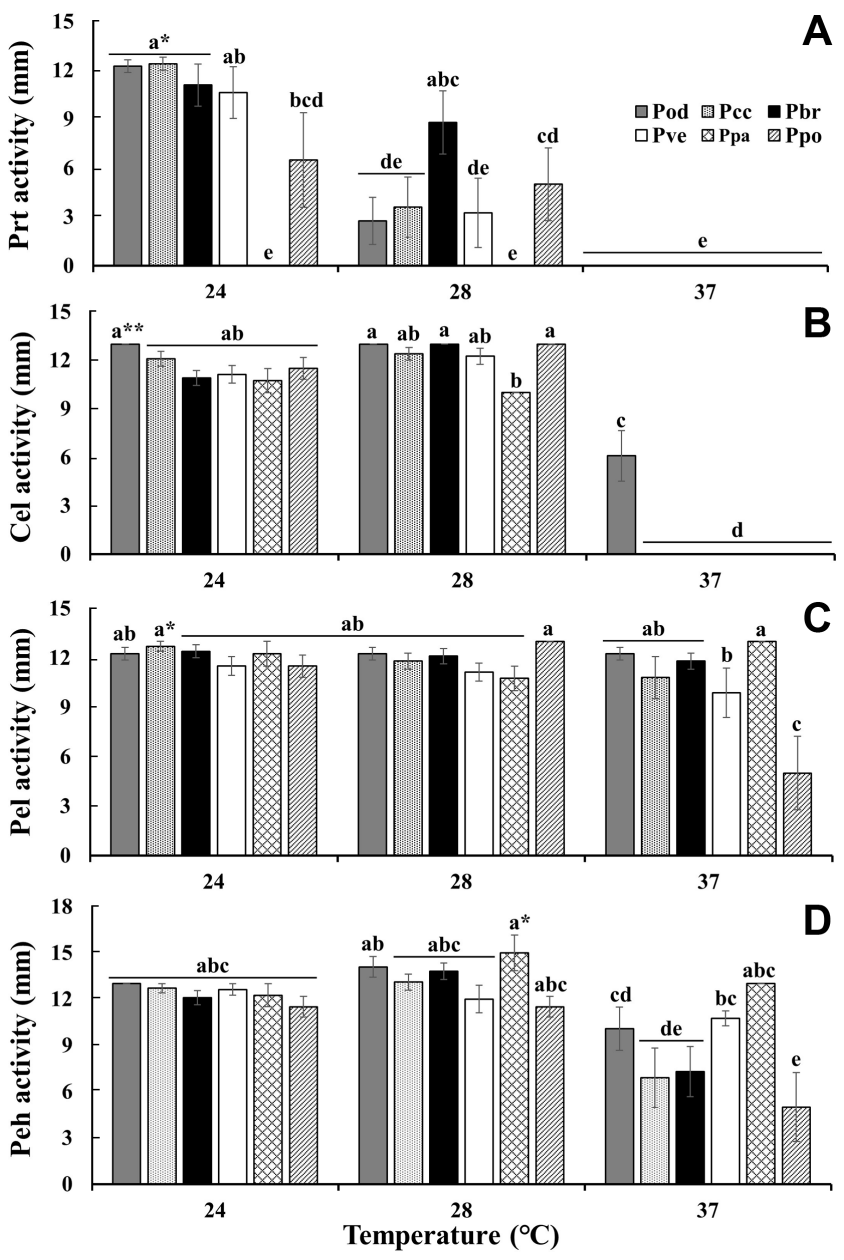

Fig. 6. Comparison of plant cell-wall degrading enzyme activity of Pectobacterium species at $24^{\circ} \mathrm{C}, 28^{\circ} \mathrm{C}$ and $37^{\circ} \mathrm{C}$. The diameter of halo response was measured for each enzyme activity: protease (Prt) (A), cellulase (Cel) (B), pectate lyase (Pel) (C), and polygalacturonase (Peh) (D). Pod, P. odoriferum; Pcc, P. carotovorum subsp. carotovorum; Pbr, $P$. brasiliense; Pve, $P$. versatile; Ppa, $P$. parmentieri; Ppo, $P$. polaris. Different letters indicate significant difference between species in an enzyme activity test according to ANOVA with Duncan test at $* P<0.05$ or $* * P<0.01$.

pathogenicity was not observed at $37^{\circ} \mathrm{C}$. The swimming motility of the reference $\mathrm{Pa}$ strain was low even at $24^{\circ} \mathrm{C}$ and almost disappeared at $28^{\circ} \mathrm{C}$, which is the optimum temperature for the other six Pectobacterium spp. isolated from potato in this study. This may explain why $\mathrm{Pa}$ is rarely isolated from potato fields in South Korea. Comparison of swimming motility between three Dickeya species also showed higher impact of temperature than species and geographical origin (Golanowska et al., 2017). This study, in addition to Golanowska et al. (2017), has identified that temperature plays an important role in swimming motility.

The effect of temperature on the pectolytic activity was investigated using SL-CVP medium (Fig. 5). In contrast to the swimming motility, the pectolytic activity of Pectobacterium decreased at $37^{\circ} \mathrm{C}$ but not markedly, except for Ppo. The pectolytic activity at $37^{\circ} \mathrm{C}$ of all Pectobacterium isolates was $20-30 \%$ lower than that at $28^{\circ} \mathrm{C}$. Pectolytic activity is defined as the maceration ability involving several pectolytic enzymes. The Prt activity of the six Pectobacterium species decreased gradually as temperature increased (Fig. 6). None of the species showed Prt activity at $37^{\circ} \mathrm{C}$. All tested bacteria, except Pod, lost their Cel activity at $37^{\circ} \mathrm{C}$. The activities of $\mathrm{Cel}, \mathrm{Pel}$, and Peh were not significantly different between $24^{\circ} \mathrm{C}$ and $28^{\circ} \mathrm{C}$. The Peh activity of Pcc, Pbr, and Ppo at $37^{\circ} \mathrm{C}$ was half of that at $28^{\circ} \mathrm{C}$, but Pel activity showed no change except for Ppo. It is well known that PCWDEs are controlled by quorum sensing (QS), and the QS signal molecule, $N$-(3-oxohexanoyl)-Lhomoserine lactone, is not detectable at $37^{\circ} \mathrm{C}$ (Hasegawa et al., 2005; Põllumaa et al., 2012; Saha et al., 2015). Golanowska et al. (2017) showed that Cel activity of Dickeya species was mainly regulated by temperature, but there was a larger effect of species on pectinase and Prt activities. In this study, Cel and Prt appeared to be strongly affected by high temperature, but Pel and Peh were only slightly affected by both species and temperature.

Our results showed that Pod, Pcc, Pbr, and Pve were the most prevalent Pectobacterium species isolated from potato and napa cabbage fields in South Korea. In addition to these four species, two isolates each of Ppa and Ppo were isolated. Although Pod is usually isolated from vegetables in South Korea, the most isolated Pectobacterium strains in potato fields were identified as Pod rather than Pcc or Pbr as in other countries (Duarte et al., 2004). The high prevalence of Pod may be caused by crop rotation of potato with napa cabbage in South Korea; further studies are required to verify this. The high potato cultivation temperature may limit the growth of $P$. atrosepticum in Korea. In a previous study, pathogenicity was lost in both the mutants of flagella, the major organs associated with motility, and the mutants of the QS related gene (Lee et al., 2013). Considering this, it is suggested that the pathogenicity loss of isolated Pectobacterium at $37^{\circ} \mathrm{C}$ was caused by loss of motility and PCWDE activity at $37^{\circ} \mathrm{C}$. These data suggest that future increases in temperature as a result of climate change can change the population dynamics of Pectobacterium.

\section{Acknowledgments}

This research was supported by the Rural Development Administration (RDA) fund PJ01127802. 


\section{Electronic Supplementary Material}

Supplementary materials are available at The Plant Pathology Journal website (http://www.ppjonline.org/).

\section{References}

Ahmed, F. A., Larrea-Sarmiento, A., Alvarez, A. M. and Arif, M. 2018. Genome-informed diagnostics for specific and rapid detection of Pectobacterium species using recombinase polymerase amplification coupled with a lateral flow device. Sci. Rep. 8:15972.

Brady, C. L., Cleenwerck, I., Venter, S. N., Engelbeen, K., De Vos, P. and Coutinho, T. A. 2010. Emended description of the genus Pantoea, description of four species from human clinical samples, Pantoea septica sp. nov., Pantoea eucrina sp. nov., Pantoea brenneri sp. nov. and Pantoea conspicua sp. nov., and transfer of Pectobacterium cypripedii (Hori 1911) Brenner et al. 1973 emend. Hauben et al. 1998 to the genus as Pantoea cypripedii comb. nov. Int. J. Syst. Evol. Microbiol. 60:2430-2440.

Czajkowski, R., Kaczyńska, N., Jafra, S., Narajczyk, M. and Lojkowska, E. 2017. Temperature-responsive genetic loci in pectinolytic plant pathogenic Dickeya solani. Plant Pathol. 66:584-594.

Charkowski, A. O. 2018. The changing face of bacterial soft-rot diseases. Annu. Rev. Phytopathol. 56:269-288.

Dees, M. W., Lysøe, E., Rossmann, S., Perminow, J. and Brurberg, M. B. 2017. Pectobacterium polaris sp. nov., isolated from potato (Solanum tuberosum). Int. J. Syst. Evol. Microbiol. 67:5222-5229.

Duarte, V., de Boer, S. H., Ward, L. J. and Oliveira, A. M. R. 2004. Characterization of atypical Erwinia carotovora strains causing blackleg of potato in Brazil. J. Appl. Microbiol. 96:535-545.

Gardan, L., Gouy, C., Christen, R. and Samson, R. 2003. Elevation of three subspecies of Pectobacterium carotovorum to species level: Pectobacterium atrosepticum sp. nov., Pectobacterium betavasculorum sp. nov. and Pectobacterium wasabiae sp. nov. Int. J. Syst. Evol. Microbiol. 53:381-391.

Golanowska, M., Kielar, J. and Lojkowska, E. 2017. The effect of temperature on the phenotypic features and the maceration ability of Dickeya solani strains isolated in Finland, Israel and Poland. Eur. J. Plant Pathol. 147:803-817.

Hasegawa, H., Chatterjee, A., Cui, Y. and Chatterjee, A. K. 2005. Elevated temperature enhances virulence of Erwinia carotovora subsp. carotovora strain EC153 to plants and stimulates production of the quorum sensing signal, $N$-acyl homoserine lactone, and extracellular proteins. Appl. Environ. Microbiol. 71:4655-4663.

Hauben, L., Moore, E. R., Vauterin, L., Steenackers, M., Mergaert, J., Verdonck, L. and Swings, J. 1998. Phylogenetic position of phytopathogens within the Enterobacteriaceae. Syst. Appl. Microbiol. 21:384-397.
Hélias, V., Hamon, P., Huchet, E., Wolf, J. V. D. and Andrivon, D. 2012. Two new effective semiselective crystal violet pectate media for isolation of Pectobacterium and Dickeya. Plant Pathol. 61:339-345.

Kang, H. W., Kwon, S. W. and Go, S. J. 2003. PCR-based specific and sensitive detection of Pectobacterium carotovorum ssp. carotovorum by primers generated from a URP-PCR fingerprinting-derived polymorphic band. Plant Pathol. 52:127133.

Khayi, S., Cigna, J., Chong, T. M., Quêtu-Laurent, A., Chan, K. G., Hélias, V. and Faure, D. 2016. Transfer of the potato plant isolates of Pectobacterium wasabiae to Pectobacterium parmentieri sp. nov. Int. J. Syst. Evol. Microbiol. 66:5379-5383.

Koh, Y. J., Kim, G. H., Lee, Y. S., Sohn, S. H., Koh, H. S., Kwon, S., Heu, S. and Jung, J. S. 2012. Pectobacterium carotovorum subsp. actinidiae subsp. nov., a new bacterial pathogen causing canker-like symptoms in yellow kiwifruit, Actinidia chinensis. N. Z. J. Crop Hortic. Sci. 40:269-279.

Kumar, S., Stecher, G. and Tamura, K. 2016. MEGA7: molecular evolutionary genetics analysis version 7.0 for bigger datasets. Mol. Biol. Evol. 33:1870-1874.

Kwon, Y.-A., Kwon, W.-T., Boo, K.-O. and Choi, Y. 2007. Future projections on subtropical climate regions over South Korea using SRES A1B data. J. Korean Geogr. Soc. 42:835-850 (in Korean).

Larkin, M. A., Blackshields, G., Brown, N. P., Chenna, R., McGettigan, P. A., McWilliam, H., Valentin, F., Wallace, I. M., Wilm, A., Lopez, R., Thompson, J. D., Gibson, T. J. and Higgins, D. G. 2007. Clustal W and Clustal X version 2.0. Bioinformatics 23:2947-2948.

Lebecka, R., Flis, B. and Murawska, Z. 2018. Comparison of temperature effects on the in vitro growth and disease development in potato tubers inoculated with bacteria Pectobacterium atrosepticum, $P$. carotovorum subsp. carotovorum and Dickeya solani. J. Phytopathol. 166:654-662.

Lee, D. H., Kim, J.-B., Lim, J.-A., Han, S.-W. and Heu, S. 2014. Genetic diversity of Pectobacterium carotovorum subsp. brasiliensis isolated in Korea. Plant Pathol. J. 30:117-124.

Lee, D. H., Lim, J.-A., Lee, J., Roh, E., Jung, K., Choi, M., Oh, C., Ryu, S., Yun, J. and Heu, S. 2013. Characterization of genes required for the pathogenicity of Pectobacterium carotovorum subsp. carotovorum Pcc21 in Chinese cabbage. Microbiology 159:1487-1496.

Li, L., Yuan, L., Shi, Y., Xie, X., Chai, A., Wang, Q. and Li, B. 2019. Comparative genomic analysis of Pectobacterium carotovorum subsp. brasiliense SX309 provides novel insights into its genetic and phenotypic features. BMC Genomics 20:486.

Mansfield, J., Genin, S., Magori, S., Citovsky, V., Sriariyanum, M., Ronald, P., Dow, M., Verdier, V., Beer, S. V., Machado, M. A., Toth, I., Salmond, G. and Foster, G. D. 2012. Top 10 plant pathogenic bacteria in molecular plant pathology. Mol. Plant Pathol. 13:614-629.

Nabhan, S., De Boer, S. H., Maiss, E. and Wydra, K. 2012. Taxo- 
nomic relatedness between Pectobacterium carotovorum subsp. carotovorum, Pectobacterium carotovorum subsp. odoriferum and Pectobacterium carotovorum subsp. brasiliense subsp. nov. J. Appl. Microbiol. 113:904-913.

Nabhan, S., De Boer, S. H., Maiss, E. and Wydra, K. 2013. Pectobacterium aroidearum sp. nov., a soft rot pathogen with preference for monocotyledonous plants. Int. J. Syst. Evol. Microbiol. 63:2520-2525.

No, J.-N., Yoo, M.-S., Park, D. S., Kim, J.-G. and Yoon, B. S. 2009. Development of a new PCR method for detection of Pectobacterium carotovorum. Korean J. Microbiol. 45:306311 (in Korean).

Oulghazi, S., Cigna, J., Lau, Y. Y., Moumni, M., Chan, K. G. and Faure, D. 2019. Transfer of the waterfall source isolate Pectobacterium carotovorum M022 to Pectobacterium fontis sp. nov., a deep-branching species within the genus Pectobacterium. Int. J. Syst. Evol. Microbiol. 69:470-475.

Park, D. H., Kim, J. S., Lee, H. G., Hahm, Y. I. and Lim, C. K. 1999. Black leg of potato plants by Erwinia carotovora subsp. atroseptica. Plant Dis. Agric. 5:64-66 (in Korean).

Pédron, J., Bertrand, C., Taghouti, G., Portier, P. and Barny, M. A. 2019. Pectobacterium aquaticum sp. nov., isolated from waterways. Int. J. Syst. Evol. Microbiol. 69:745-751.

Põllumaa, L., Alamäe, T. and Mäe, A. 2012. Quorum sensing and expression of virulence in pectobacteria. Sensors (Basel) 12:3327-3349.

Portier, P., Pédron, J., Taghouti, G., Fischer-Le Saux, M., Caullireau, E., Bertrand, C., Laurent, A., Chawki, K., Oulgazi, S., Moumni, M., Andrivon, D., Dutrieux, C., Faure, D., Hélias, V. and Barny, M. A. 2019. Elevation of Pectobacterium carotovorum subsp. odoriferum to species level as Pectobacterium odoriferum sp. nov., proposal of Pectobacterium brasiliense sp. nov. and Pectobacterium actinidiae sp. nov., emended description of Pectobacterium carotovorum and description of Pectobacterium versatile sp. nov., isolated from streams and symptoms on diverse plants. Int. J. Syst. Evol. Microbiol. 69:3207-3216.

Roh, E., Lee, S., Lee, Y., Ra, D., Choi, J., Moon, E. and Heu, S. 2009. Diverse Antibacterial activity of Pectobacterium carotovorum subsp.carotovorum isolated in Korea. J. Microbiol. Biotechnol. 19:42-50.

Saha, N. D., Chaudhary, A., Singh, S. D., Singh, D., Walia, S. and Das, T. K. 2015. Plant pathogenic microbial communication affected by elevated temperature in Pectobacterium carotovorum subsp. carotovorum. Curr. Microbiol. 71:585-593.

Saitou, N. and Nei, M. 1987. The neighbor-joining method: a new method for reconstructing phylogenetic trees. Mol. Biol. Evol. 4:406-425.

Sarfraz, S., Riaz, K., Oulghazi, S., Cigna, J., Sahi, S. T., Khan, S. H. and Faure, D. 2018. Pectobacterium punjabense sp. nov., isolated from blackleg symptoms of potato plants in Pakistan. Int. J. Syst. Evol. Microbiol. 68:3551-3556.

Seo, S.-T., Koo, J.-H., Hur, J.-H. and Lim, C.-K. 2004. Characterization of Korean Erwinia carotovora strains from potato and
Chinese cabbage. Plant. Pathol. J. 20:283-288.

Shirshikov, F. V., Korzhenkov, A. A., Miroshnikov, K. K., Kabanova, A. P., Barannik, A. P., Ignatov, A. N. and Miroshnikov, K. A. 2018. Draft genome sequences of new genomospecies "Candidatus Pectobacterium maceratum" strains, which cause soft rot in plants. Genome Announc. 6:e0260-18.

Skelsey, P., Humphris, S. N., Campbell, E. J. and Toth, I. K. 2018. Threat of establishment of non-indigenous potato blackleg and tuber soft rot pathogens in Great Britain under climate change. PLoS ONE 13:e205711.

Thapa, S. P., Park, H. R., Lim, C. K. and Hur, J. H. 2011. Phylogeny of the Korean Erwinia species as determined by comparison of $16 \mathrm{~S}$ rDNA sequences. J. Agric. Life Environ. Sci. 23:62-69.

Toth, I. K., Bell, K. S., Holeva, M. C. and Birch, P. R. 2003. Soft rot erwiniae: from genes to genomes. Mol. Plant Pathol. 4:17-30.

van der Wolf, J. M., de Haan, E. G., Kastelein, P., Krijger, M., de Haas, B. H., Velvis, H., Mendes, O., Kooman-Gersmann, M. and van der Zouwen, P. S. 2017. Virulence of Pectobacterium carotovorum subsp. brasiliense on potato compared with that of other Pectobacterium and Dickeya species under climatic conditions prevailing in the Netherlands. Plant Pathol. 66:571-583.

Waleron, M., Waleron, K. and Lojkowska, E. 2014. Characterization of Pectobacterium carotovorum subsp. odoriferum causing soft rot of stored vegetables. Eur. J. Plant Pathol. 139:457-469.

Waleron, M., Waleron, K., Podhajska, A. J. and Łojkowska, E. 2002. Genotyping of bacteria belonging to the former Erwinia genus by PCR-RFLP analysis of a $r e c A$ gene fragment. Microbiology 148:583-595.

Waleron, M., Misztak, A., Waleron, M., Franczuk, M., Wielgomas, B. and Waleron, K. 2018. Transfer of Pectobacterium carotovorum subsp. carotovorum strains isolated from potatoes grown at high altitudes to Pectobacterium peruviense sp. nov. Syst. Appl. Microbiol. 41:85-93.

Waleron, M., Misztak, A., Jońca, J., Furmaniak, M., Waleron, M. M. and Waleron, K. 2019a. First report of 'Candidatus Pectobacterium maceratum' causing soft rot of potato in Poland. Plant Dis. 103:1409.

Waleron, M., Misztak, A., Waleron, M., Franczuk, M., Jońca, J., Wielgomas, B., Mikiciński, A., Popović, T. and Waleron, K. 2019b. Pectobacterium zantedeschiae sp. nov. a new species of a soft rot pathogen isolated from Calla lily (Zantedeschia spp.). Syst. Appl. Microbiol. 42:275-283.

Waleron, M., Misztak, A., Waleron, M., Jonca, J., Furmaniak, M. and Waleron, K. 2019c. Pectobacterium polonicum sp. nov. isolated from vegetable fields. Int. J. Syst. Evol. Microbiol. 69:1751-1759.

Yahiaoui-Zaidi, R., Ladjouzi, R. and Benallaoua, S. 2010. Pathogenic variability within biochemical groups of Pectobacterium carotovorum isolated in Algeria from seed potato tubers. Int. J. Biotechnol. Mol. Biol. Res. 1:001-009. 